\title{
Vpliv kraja bivanja in izobrazbe staršev na intenzivnost inštrukcij
}

\author{
Evelina Perozzi \\ Fakulteta za uporabne družbene študije, Gregorčičeva 19, 5000 Nova Gorica, Slovenija \\ eperozzi@gmail.com
}

Andrej Raspor*

Fakulteta za uporabne družbene študije, Gregorčičeva 19, 5000 Nova Gorica, Slovenija andrej.raspor@fuds.si

\begin{abstract}
Povzetek:
Raziskovalno vprašanje (RV): V raziskavi smo se med drugim osredotočili na povezavo med prebivališčem in izobrazbo staršev otrok, ki obiskujejo inštrukcije ter njihovo intenzivnostjo. Za namene raziskave smo temu primerno oblikovali naslednje raziskovalno vprašanje: Ali bivališče uporabnikov in izobrazba njihovih staršev vplivata na intenzivnost inštrukcij?"

Namen: Poglavitni namen raziskave je bil ugotoviti povezavo med intenzivnostjo koriščenja inštrukcij v širši goriški regiji ter krajem bivanja in izobrazbo staršev. Osredotočili smo se na naravoslovne predmete (matematika, fizika, kemija) in en družboslovni predmet (tuj jezik).

Metoda: Anketirali smo osnovnošolce, dijake gimnazij, srednjih strokovnih in poklicnih šol, ter študente, vpisane v visokošolske študijske programe na Goriškem. Preko intervjujev z udeleženci inštrukcij in njihovimi starši smo kvantitativno raziskavo obogatili še z detajlno vsebinsko analizo o koristi inštrukcij. Opravili smo še intervjuje z učitelji fizike, kemije, matematike in angleščine, tako na osnovnošolskem, kot srednješolskem nivoju izobraževanja, in na podlagi tega presodili o nujnosti in priljubljenosti inštrukcij znotraj sistema formalnega izobraževanja. Pri raziskavi smo se poslužili metode opazovanja, pri kateri smo opazovali učence, ki obiskujejo inštruktorje in se poslužujejo inštrukcij. Raziskava je potekala v obdobju šolskega leta 2016/2017.

Rezultati: Na osnovi vseh predstavljenih raziskav se je izoblikovala naslednja ključna ugotovitev; Kraj bivanja in izobrazba staršev ne vplivata na intenzivnost inštrukcij.

Organizacija: Glede na ugotovitve, da se obseg inštrukcij povečuje in da so inštruiranci preveč usmerjeni v izboljšavo ocen in ne v boljše utrjevanje snovi, bi lahko ravnatelji in dekani šol izvedli določene spremembe pri podajanju učne vsebine, učencem, dijakom in študentom. Pri sami organizaciji inštrukcij je pomembno to da so neposredno povezane za utrjevanje snovi in ne samo, da so usmerjene v izboljšanje ocen, ki so pogoj za prehodnost in vpis na fakulteto.

Družba: Prispevek je pomemben z vidika učencev, učiteljev in tudi Ministrstva za izobraževanje pri prihodnjih reformah šolskega sistema. Raziskava daje osnove, saj bi širša raziskava na to temo lahko ponudila rešitve, ki bi omejile nastajajoči razdor med učenci in učitelji, saj je raziskava pokazala, da se je uporaba inštrukcij v zadnjem času povečala. Predvsem bi se tu morali zgledovati po državah, kjer je študij zasnovan tako, da ni potrebe po dodatnih inštrukcijah.

Originalnost: Gre za prvo tako celovito raziskavo na Goriškem in v Sloveniji nasploh. Vključeni so bili vsi nivoji šolanja. Od osnovne šole, srednje šole do fakultet. Predvsem pa se kaže njena originalnost, saj je iskala odgovore o vplivih kraja bivanja in izobrazbe staršev na same inštrukcije. Omejitve/nadaljnje raziskovanje: Omejitev raziskave se kaže v tem, da smo raziskavo izvedli na Goriškem in da je bil vključen priložnostni vzorec, zato ugotovitev ne moremo prenašati na vse, saj vzorec ni uravnotežen. Na podlagi ugotovitev, bi bilo smiselno dopolniti metodologijo in izvesti raziskavo med celotno slovensko populacijo. Druga omejitev je v tem, da je bila izvedena pred COVID-19, saj se je med tem časom podajanje snovi in inštruiranje moralo prilagoditi novim razmeram.
\end{abstract}


Ključne besede: inštrukcije, izobraževanje, individualizem, konformizem, motivacija, generacije, izobrazba staršev, lokacija bivanja staršev.

\section{Uvod}

Poleg nuklearne in razširjene družine, katere želja je, da bi otroka že v zgodnji fazi otroštva pripravila na samostojnost pri delu, izobraževanju in splošnem razvoju, saj mu bo to omogočilo vključenost v sodobno družbo, sodelujejo v tem procesu tudi prijatelji, okolje ter izobraževalne ustanove s svojimi pedagoškimi delavci. Otrok tako poleg znanja razvija, poglablja in pridobiva tudi življenjsko pomembne vrednote in norme. Ob formalnemu izobraževanju se v ta proces vedno bolj vključujejo tudi inštruktorji.

Izobraževanje postaja skupna naloga družine, širše družbe ter formalnih in neformalnih izobraževalnih ustanov in organizacij. Za doseganje uspehov v izobraževalnem sistemu in $\mathrm{v}$ življenju posameznika nasploh, je vseeno $\mathrm{v}$ prvi vrsti ključna lastna odgovornost pri pridobivanju znanj in aktivna udeležba $\mathrm{v}$ izobraževalnih procesih. $\mathrm{V}$ sled tega posamezniki iščejo razne oblike pomoči. Ena takšnih oblik so inštrukcije. Gre za plačljivo obliko nudenja individualne učne pomoči pri šolskih predmetih in niso del formalnega šolskega sistema (Dedić, Jokić, Jurko, \& Puzić, 2005). Inštruktorji imajo velik vpliv na inštruiranca, saj ga v procesu inštruiranja s svojim zgledom tudi vzgajajo.

Za usmeritev pri teoretičnem raziskovanju omenjenega področja so nam služile raziskava, ki jo izvaja OECD (OECD, 2018) in raziskave Marka Braya (Bray 2006, 2014, 2016, 2003). Raziskovanje je bilo kasneje nadgrajeno z lastno raziskavo (Perozzi, 2018), ki je bila izvedena v letu 2017 in je bila sestavljena iz dveh delov. V prispevku omenjamo tudi ugotovitve omenjene raziskave. Prvi del raziskave smo izvedli s terenskim anketiranjem učencev in učenk devetih razredov osnovnih šol, dijakinj in dijakov splošnih in poklicnih srednješolskih programov ter študentk in študentov fakultet, ki so v šolskem letu 2016/2017 delovale na območju goriške regije. Naslednji del raziskave je potekal med učitelji, zaposlenimi na osnovnih in srednjih šolah goriške regije, pri čemer smo uporabili polstrukturirane intervjuje.

Kljub nenehnim spremembam in posodobitvam šolskega sistema, je koristnikov inštrukcij tudi pri nas vedno več, kar sovpada s porastom individualizacije in zavesti o lastni odgovornosti za znanje in kakovost bivanja. Pri tem se njihov osnovni namen spreminja, saj postajajo orodje za ne le popravljanje nezadostnih ocen, pač pa za izboljšanje pozitivnih ter poglabljanje znanja izbranih vsebin, ki so koristniku nujni za doseganje nadaljnjih izobraževalnih ciljev.

\section{Teoretična izhodišča}

Inštrukcije se omenjajo že med zapisi o stari Grčiji (Gardner III, Nobel, Hessler, Yawn, \& Heron, 2007), a so bile takrat reden del izobraževalnega procesa, in jasne razmejitve med izobraževanjem in inštrukcijami ni mogoče določiti. Izobraževanja so bili do vzpostavitve 
javnega šolstva največkrat deležni le izbranci, zato je bilo število učencev na učitelja majhno, še posebej tam, kjer so izobraževali le plemiški stan (Joyal, Yardley, \& McDougall, 2009). S spremembami izobraževalnih sistemov se je spreminjala tudi vloga in oblika inštrukcij in te postajajo vedno bolj razširjen dodatek $\mathrm{k}$ formalnemu izobraževanju, to pa predvsem $\mathrm{v}$ državah $\mathrm{v}$ tranziciji in razvoju, delno tudi pri nas.

\subsection{Formalno izobraževanje in $\mathrm{z}$ izobraževanjem povezane učne težave}

V Sloveniji je formalno izobraževanje javno in v pristojnosti države. Zaradi vsesplošne dostopnosti pogosto ni deležno ugleda, ki bi si ga zaslužilo, oz. se te dobrine ne ceni dovolj. Za uspešno aktivno življenje posameznika je pridobitev formalne izobrazbe ključna. Javno formalno izobraževanje je kolektivno, saj je njegov cilj formirati družbenokoristne državljane, medtem ko individualno izobraževanje oblikuje značaj posameznika, razvija njegove sposobnosti samodiscipline in prepoznavanja lastnih sposobnosti in njihov razvoj (Pavitra, 2002). Slogan »na znanju temelječa družba« je direktno povezan s poglavitnimi nameni izobraževanja, kot so bili prvič zapisani v dokumentu Evropske komisije (1996). Slovenija je izvedla prenovo izobraževalnega sistema in s prilagajanjem šolanja smernicam Lizbonske strategije in Evropske unije, prešla na devetletno osnovno šolanje. V srednješolsko izobraževanje je bil uveden dualni sistem, na terciarni stopnji pa se je izvedlo prehod na bolonjski sistem izobraževanja. Prenova slovenskega šolstva je potekala na več nivojih. tako na strukturnem, kot na vsebinskem, zasnovana in predstavljena pa je bila v Beli knjigi o izobraževanju (Zgaga, Pluško, Krek, Zdenko, \& Marjanovič-Umek, 2004). Trenutni sistem vzgoje in izobraževanja pri nas se začenja s vrtčevsko predšolsko vzgojo in poteka preko osnovnošolske in srednješolske stopnje vse do doktorskega študija, izobraževanje pa poteka tako v javnih kot tudi v zasebnih vrtcih, šolah oziroma univerzah. Kvaliteta posameznih šol in njihova primerjava poteka $\mathrm{z}$ zunanjimi preverjanji izobraževalnih rezultatov, na primer $\mathrm{s}$ preverjanjem znanj ob zaključevanju triad na osnovnih šolah, srednješolski zaključni izpiti oziroma matura.

Skozi celoten proces šolanja se pojavljajo težave, povezane z učenjem. Pomembno je, da znamo te težave že zelo zgodaj prepoznati. Glavni cilji diagnostičnega ocenjevanja težav pri učenju so (Grašič idr., 2010):

- identificirati (velja za učenca/dijaka/študenta) splošna močna področja in šibkosti,

- ugotoviti aktualno raven učnega funkcioniranja in dosežkov,

- razložiti pomanjkanje napredka,

- identificirati vidike izvajanja, ki so značilni za določeno vrsto težav,

- identificirati specifična področja kompetentnosti,

- razumeti stil učenja in

- ugotoviti pokazatelje v kurikulumu, ki posameznika zanimajo ali motivirajo.

Večina učiteljev v osnovni šoli za učence s posebnimi potrebami, med katerimi je največ takšnih z izrazitimi specifičnimi učnimi težavami oziroma s primanjkljaji na posameznih 
učnih področjih z vidika storilnosti, o teh učencih navaja sledeče (Peček, Čuk, \& Lesar, 2010):

- niso zmožni koncentracije,

- $\quad$ so površni, ne vztrajajo, so pri delu počasni in počasi dojemljivi,

- niso aktivni in iniciativni,

- imajo slabe delavne navade,

- med zaposlitvami se igrajo in klepetajo,

- niso razgledani,

- imajo nizke izobrazbene aspiracije.

Učne težave, opredeljene za nivo osnovnošolskega izobraževanja, uporabljajo pa se lahko tudi v srednjem izobraževanju, se razdelijo v pet osnovnih stopenj pomoči (Magajna, Čačinovič Vogrinčič, Kavkler, Pečjak, \& Bregar Golobič, 2008):

- pomoč učitelja neposredno pri skupinskem ali nivojskem pouku, dopolnilnem pouku in v okviru programa podaljšanega bivanja,

- pomoč šolske svetovalne službe in/ali mobilne specialne pedagoške službe,

- dodatna individualna in/ali skupinska pomoč, ki jo lahko izvajajo specialni pedagogi, učitelji in svetovalni delavci,

- strokovno mnenje in pomoč zunanje ustanove,

- poseben program s prilagojeno izvedbo pouka in dodatno strokovno pomočjo.

Povezavo med formalnim izobraževanjem in inštrukcijami vidimo pri dopolnilnem pouku ali konzultacijah. Tam se lahko učitelji individualno posvetijo posamezniku, vendar pa v učnem programu predpisani čas za dopolnilne ure ne dopušča vedno poglobljenega dela.

\subsection{Inštrukcije}

Zakaj nastanejo inštrukcije in kaj z njimi pridobimo? Neformalno izobraževanje je vsaka namerna, organizirana in načrtovana oblika izobraževanja, ki se opravlja zunaj okvirov rednega formalnega šolskega sistema in ne poteka na konvencionalen način, ter naslavlja le posamezne ciljne skupine uporabnikov (Perozzi, 2018). Takšna oblika izobraževanja se lahko izvaja bodisi neposredno na delu, ali kot samostojna aktivnost posamezne ustanove ali civilnodružbene skupine, lahko pa nudi podporo formalnemu izobraževanju, pri čemer je njen namen poglabljanje in posodabljanje že obstoječega znanja. Inštrukcije na vseh nivojih formalnega šolanja sodijo med neformalne oblike izobraževanja .

V kolikor za definicijo inštrukcij povzamemo Dedića, ta z ostalimi avtorji definira inštrukcije kot »dodatno poučevanje šolskih predmetov $\mathrm{v}$ zameno za plačilo izven formalnega poučevanja, kjer pa je izvzeto izobraževanje izven šolskih dejavnosti, kot je šport ali učenje dodatnega tujega jezika« (Dedić idr., 2005). Obstajajo tudi druge opredelitve. Bray (1999) namesto pojma inštrukcij uporablja zvezo »izobraževanje v senci«, pri čemer poudarja, da so pri tej vrsti izobraževanja vsebine skladne tistim, ki jih uporabnikom podajajo formalne 
izobraževalne ustanove. Načini in načela formalnega izobraževanja so jasno določeni, medtem ko pri inštrukcijah niso tako jasno opredeljeni (Bray, 2006). Ne nazadnje je lahko inštruiranec pri inštrukcijah fokusiran $\mathrm{v}$ le en problem (podrobno razjasnitev ali utrditev znanja določenih vsebin), pri čemer ne gre le za ponavljanje vsebin, ki jih ima ta v okviru formalnih učnih programov.

$\mathrm{V}$ tem kontekstu lahko inštrukcije ponujajo dodatno zasebno mentorstvo (inštruiranje) pri osvajanju in poglabljanju učnih vsebin, ki jih je podal formalni učni sistem. Brey navede tri osnovne pogoje: (1) zasebna oblika poučevanja za plačilo, (2) dodatno izobraževanje ob rednem šolanju in »izobraževanje v senci« (3) temeljiti morajo na primarnih predmetih formalnega izobraževanja (Bray, 2014).

Pri definiciji pojma inštrukcije je potrebno gledati tudi $\mathrm{z}$ vidika števila inštruirancev. Inštrukcije so lahko omejene zgolj na individualno poučevanje »ena na ena«, ki lahko vključuje tudi manjše skupine, lahko pa se jih v opredelitev vključi poučevanje večjih skupin, na primer hkratno predavanje večim inštruirancem $\mathrm{v}$ večjih predavalnicah. $\mathrm{S}$ pojavom različnih možnosti za delo od doma, se pojavljajo tudi t.i. spletne (ang. on-line) inštrukcije, ki se jih vse pogosteje realizira in neposredno prenaša preko raznih socialnih omrežij (Ventura \& Jang, 2010). Te večinoma potekajo v živo, kar omogoča neposredno delo, a se pogosto uporablja tudi video posnetke (Bray idr., 2016).

V kolikor se navežemo na še enega slovenskega avtorja, Kranjc (1979) inštrukcije ali »izobraževanje $\mathrm{v}$ senci« opredeli kot neformalno obliko poučevanja, ki poteka zunaj formalnega izobraževalnega procesa. Inštrukcije predstavljajo podporo formalnemu procesu in potekajo pretežno individualno ali v manjših skupinah, osnovane so na učni snovi, ki se jo obravnava $v$ formalnem učnem načrtu. Ključni namen inštrukcij je pridobivanje znanja, ki je potrebno za uspešno izpolnjevanje načrta formalnega izobraževanja. Inštruktor, ki je lahko bodisi učitelj, starš, sorojenec, prijatelj ali kdo drug, mora biti pozoren, da pri delu uporablja pravilne učne postopke (Krajnc, 1979). Plačila ne opredeljuje kot pogoj za definicijo inštrukcij. Gre za utrditev znanja, ki je bilo pridobljeno v okviru rednih šolskih programov, s ciljem izboljšanja znanja ali ocene. V zadnjem času se pojavljajo težnje mlajših generacij po izobraževanju, da bi na ta način zadostili svoji individualnosti, tekmovalnosti, ambicioznosti, neučakanosti in materializmu, ki so zanje značilni, kar je zelo vplivalo na porast uporabe inštrukcij (Perozzi \& Raspor, 2020).

Za potrebe te študije smo pojem inštrukcij definirali kot obliko poučevanja, ki poteka zunaj sistema formalnega izobraževanja, se izvaja proti plačilu in je osnovana izključno na šolskih predmetih. Izvaja jih inštruktor, ki je starejši od učenca in prevzema aktivno vlogo in odgovornost pri podajanju učne vsebine, preverjanju pomnjenja in razumevanja in preverjanju znanja na konkretnih primerih. Iz definicije sta izvzeti pomoč soudeležencev izobraževanja in članov družine. Skratka, z inštrukcijami si tisti, ki jih izvajajo bodisi popravljajo svoj ekonomski status, ali pa jih izvajajo kot svojo osnovno dejavnost. Velikokrat zelo dobro 
poznajo zahteve posameznega nosilca predmeta in zato lahko inštruirancu svetujejo, kaj je tisto, kar mu bo pomagalo izboljšati oceno.

\subsection{Inštrukcije v sodobnem času}

Inštrukcije niso nov pojav, kot smo predhodno že omenili. V članku Researching Private Supplementary Tutoring (Bray idr., 2016) avtorji navajajo, da lahko omembe mentorstva v literaturi najdemo že v prvi polovici 20. stoletja. Mauritius Foondun (Mauritius Ministry of Education and Science 1994, str. 488) omenja šolskega ravnatelja, ki je leta 1901 ocenil mentorstvo oziroma inštrukcije kot negativen pojav, ki ga sam ni bil sposoben preprečiti. Vodja Mavricijske kraljevske akademije se je pritožila (v Mauritius Ministry of Education and Science, 1994, str. 1-2), ker je dvanajst njenih delavnih kolegov ob rednem delu za dodatno plačilo ponujalo tudi do 33 ur zasebnega mentorstva (Bray idr., 2016). Iz tega je jasno, da prisotnost plačanih inštrukcij ni nov pojav in kot tak ni značilen zgolj za eno okolje.

Obseg inštrukcij, kot navaja Bray (2016), se od države do države razlikuje. Tako v Afriki intenzivnost inštrukcij raste. Uradna študija je pokazala, da je 81 \% egiptovskih gospodinjstev plačevalo svojim otrokom inštrukcije na srednjih šolah, v osnovnih šolah je bil delež $50 \%$ (Sobhy, 2012, str. 49). V Aziji, še posebej na Kitajskem, so inštrukcije že dolgo pomemben spremljevalec formalnega izobraževanja. Zanje je značilno, da inštrukcije, $z$ namenom zviševanja svojega življenjskega standarda, izvajajo učitelji, ki so sicer zaposleni v formalnem izobraževalnem sistemu. Zanimanje za inštrukcije vedno bolj narašča tudi $v$ Indiji in Pakistanu. Tu jih poleg učiteljev nudijo tudi za ta namen ustanovljena specializirana podjetja. Na območju držav varšavskega pakta ter srednje in severne Azije se inštrukcij niso posluževali vse do uveljavitve tržnega gospodarstva, po razpadu Sovjetske Zveze. V južni Evropi, s Ciprom, Malto in Grčijo, se inštrukcij poslužujejo že desetletja in tam veljajo za običajen del srednješolskega izobraževanja. Tudi zahodna Evropa se ponaša z dolgo tradicijo mentorstva in inštrukcij. Te so se v večjem obsegu pričele pojavljati sočasno s porastom želje po povečanju podjetne konkurenčnosti, predvsem $\mathrm{v}$ kontekstu povečevanja delovne mobilnosti in kompetenc, in veljajo za pomemben del trženja znanja. S tem postajajo bolj in bolj družbeno sprejemljive (Bray idr., 2016) in posledično povpraševanje po teh storitvah raste.

V državah severne Evrope se beleži najnižja stopnja uporabe inštrukcij. Skandinavija prednjači v ohranitvi tradicije, ki se trudi ustrezno izpolnjevati zahteve in želje svojih učencev v sistemu javnega šolstva. Tam so dodatnih inštrukcij deležni le nekateri posamezniki, da lahko brez težav sledijo svojim vrstnikom, in se izvajajo v okviru javnega šolstva (Sahlberg, 2014), ter niso posebej plačljive. Finska slovi kot država, kjer se izobraževanje izvaja na način, da ob obveznem šolskem delu, ki je osnovan na enakosti, ni potrebe po dodatnih inštrukcijah. Slednje se potrjuje tudi v študiji OECD, kjer je razlika med najbolj in najmanj uspešnim učencem minimalna, v primerjavi z ostalimi državami (OECD, 2018). Ista študija ugotavlja, da to dosegajo v glavnem z etičnim usmerjanjem v izobraževanju, ki je bazirano na medsebojnem spoštovanju, zaupanju in pomoči vsakomur, ki je je potreben, vse dokler jo 
potrebuje (OECD, 2018). Otrok ne deli na boljše ali slabše, marveč se jih že v začetnih fazah izobraževanja spodbuja k samostojnemu učenju in iskanju ter razvijanju lastnih interesov (Morgan, 2014). Vsak je za nekaj dober in lahko postane v tem najboljši. Študij na visokih šolah tako nadaljuje kar 66 \% dijakov. Raziskave opozarjajo še, da se finski otroci po svoji samooceni uvrščajo nekako med povprečje, dejansko pa so v vrhu lestvic po dosežkih (Škalič, 2016).

V Avstraliji, Kanadi, ZDA in Latinski Ameriki inštrukcije niso dosegle razsežnosti, kakršne so bile deležne v Aziji in južni in srednji Evropi. V Argentini in Braziliji pa se že kažejo očitni znaki razširjenosti inštrukcij (Bray idr., 2016).

\subsection{Kje lahko iščemo vzroke za nastanek inštrukcij}

Med temeljnimi vzvodi povečevanja povpraševanja po inštrukcijah Kassotakis in Verdis (Kassotakis \& Verdis, 2013, str. 94) navajata: (1) povečevanje zanimanja za izobraževanje in (2) omejevanje prostih vpisnih mest na visokih šolah. Vzroki so pogosto političnogospodarske narave. S spremembo oblasti v Grčiji so bolj levičarsko usmerjeni učitelji izgubili zaposlitev. Inštrukcije so jim zagotavljale preživetje.

Druge razloge za potrebo po inštrukcijah lahko iščemo tudi $\mathrm{v}$ nezadovoljstvu staršev $\mathrm{s}$ kakovostjo formalnega izobraževalnega sistema in njihovi želji ali želji njihovih otrok po boljših ocenah in posledično bolj kakovostni izobrazbi (Čakš, 2004). Na Finskem je na primer ocenjena stopnja zaupanja v kakovost šolskega sistema zelo visoka, kar 90 \%, zato inštrukcij praktično nimajo (Škalič, 2016). Dodatno znanje pa ni edini motiv za obiskovanje inštrukcij, saj učenci ne iščejo samo znanja, kot smo tudi sami ugotovili, ampak lažjo pot do boljših ocen (Perozzi \& Raspor, 2020).

Evropska unija si je zastavila cilj, da bi polovica prebivalstva med 25 in 45 letom do leta 2020 dosegla terciarno stopnjo izobrazbe, kar očitno povečuje interes za terciarno izobraževanje. Če se ozremo nekoliko v preteklost, je bilo vse do poznih sedemdesetih let izobraževanje nad srednješolsko stopnjo nedostopno za otroke iz manj premožnih družin. Takrat se je po srednji šoli na nadaljevalno šolanje na univerzah vpisalo le okoli $5 \%$ vseh 18 letnikov. Modernizacija in pospešen tehnološki napredek v gospodarstvu ustvarjata potrebe po visoko izobraženih delavcih, ki bi povečevali produktivnost in zagotavljali konkurenčnost. Bolj izobraženim pa to vsaj v teoriji omogoča boljše zaposlitvene možnosti. V zadnjem času so se spremenile tudi kompetence, ki jih potrebujejo zaposleni. Predvsem gre tu za računalniška in druga znanja, povezana s uporabo modernih tehnologij. Rapuš Pavel in Stepišnik Perdih (Rapuš \& Stepišnik Perdih, 2007) ugotavljata, da je eden izmed pomembnih dejavnikov ranljivosti, ki prispeva $\mathrm{k}$ naraščanju tveganja izključenosti, nizka stopnja izobrazbe. Novo revščino naj bi v prihodnje bolj določali primanjkljaji v izobrazbi, neznanje, nekvalificiranost oz. napačna kvalificiranost. Uporabniki storitve inštrukcij si ne želijo postati družbeni izobčenci, in jim te predstavljajo motivacijo in možnost za doseganje karseda dobrih rezultatov (Reddy, Lebani, \& Davidson, 2003). 
$\mathrm{V}$ primerjavi s formalnim ima izobraževanje z inštrukcijami navadno manj teoretskega dela in bolj poudarja prakso. Aktivnega sodelovanja udeležencev je več, vključeni so bolj raznoliki pristopi, samo učenje pa je bolj prilagojeno posamezniku. Razlage so bolj preproste, kot je to značilno pri podajanju znanja v sklopu formalnega šolanja, inštruiranec lahko takoj pridobi povratno informacijo o svojem delu, kar ga dodatno motivira in vzpodbuja k nadaljnjemu delu. Inštruktor lahko nudi precej več individualne podpore in pomoči $\mathrm{z}$ uporabo preprostejšega besedišča, se sproti prilagaja in v proces vključuje različne metode dela, glede na inštruirančev odziv. Vse to pomaga pri učenju in pripomore k razreševanju učnih težav posameznika, ki jih lahko inštruktor zaznava in rešuje neposredno. S takim načinom dela inštruiranec lažje ponotranji znanja in razvije potrebno samokorekcijo. Njegovo znanje postaja aktivno in uporabno, kar izboljšuje samozavest in spodbuja razvoj pozitivnih osebnostnih lastnosti. Ni nezanemarljivo tudi to da imajo inštruiranci do inštruktorjev višja pričakovanja kot do svojih pedagoških delavcev v javnem šolstvu, saj prevladuje mnenje, da bi jim moral bolj individualen način dela omogočiti uspešno nadaljevanje formalnega izobraževanja (Bray \& Kwok, 2003, str. 611-620).

Tuje raziskave nakazujejo na vse večjo potrebo po inštrukcijah iz naravoslovnih predmetov, fizike, kemije, matematike in tujih jezikov, predvsem na srednjih šolah, kar se opaža v razvitih deželah in tistih v razvoju (Bray, 2006). Podobno stanje imamo tudi v Sloveniji, kar nakazuje, da morda pristopi pri podajanju snovi niso ustrezni in bi jih kazalo spremeniti. Predvsem pa bi bilo potrebno narediti študij bolj zanimiv.

Nižja stopnja inštrukcij bi lahko nakazovala na uporabo boljših metod znotraj formalnega šolstva na Finskem (5\%) in v Veliki Britaniji (10 \%). Kaže pa lahko tudi na bolj motivirane učence, ki stremijo k znanju in ne iščejo le hitrih poti do dobrih ocen. Slednje je morebiti pogojeno $\mathrm{z}$ družbeno kulturo in njenimi vrednotami. Inštrukcij se poslužujejo tako manj uspešni učenci, ki bi želeli popraviti ocene, kot odlični učenci, ki se pripravljajo na spraševanja in preverjanja znanj, za doseganje odličnih ocen. Inštrukcije se zanemarljivo redko uporablja z namenom poglabljanja znanj. Največkrat se učenci inštrukcij poslužujejo pri predmetih, pri katerih je novo snov težko osvojiti brez dovolj dobrega znanja prejšnje (Jarić Dauenhauer, 2014). Gre za postopno utrjevanje znanja.

Raziskave o uporabi inštrukcij v Hong Kongu, Taiwanu in Nemčiji so pokazale, da je največji delež uporabnikov presenetljivo med študenti elitnih šol. Ti se inštrukcij poslužujejo z namenom ohranjanja visokih ocen. Pričakovanja staršev in inštruirancev so že ob vpisu na te šole visoka. Dedić in ostali avtorji (Dedić idr., 2005) navajajo, da je večina otrok, ki uporablja inštrukcije iz premožnejših družin, Braya (Bray, 2006) pa navaja, da se inštrukcij, prav z namenom, da bi zapolnili vrzeli neenotnega sistema javnega izobraževanja, poslužujejo tudi manj premožni. Učenci morajo pri prestopu izobraževalnih stopenj namreč nadoknaditi vse tisto znanje, ki ga v okviru predhodnih šol niso dobili. Nekatere države se ne zavzemajo za inštrukcije in so do njih kritične, saj naj bi ta oblika izobraževanja dodatno povečevala socialne razlike, ker si jih vsi ne morejo privoščiti. Prav to smo želeli v naši raziskavi raziskati, namreč kakšne so razlike glede na kraj bivanja in izobrazbo staršev. Zaradi 
individualizma in konformizma se povpraševanje po inštrukcijah povečuje. Inštrukcije ne služijo več zgolj popravljanju negativnih ocen in višanju le-teh, pač pa gre pri procesu za redno kontinuirano delo, za katerega javni izobraževalni sistem nima dovolj časa, saj se šole doslej še niso uspele uspešno prilagoditi individualnemu tipu aktivnega izobraževanja (Perozzi, 2018). Uspešnost takšnega učenja je odvisna od mnogih pogojev, med temi same metode inštruiranja, trajanja in organizacije inštrukcij, intenzivnosti ter motivacije inštruktorja in uporabnika (Bray, 2006).

V Sloveniji že dalj časa narašča povpraševanje po inštrukcijah, najbolj izrazito med osnovnošolci (Čakš, 2004). Naraščajoče zavedanje o vrednosti znanja in pomenu razvoja lastnega potenciala, je spodbudilo povpraševanje po inštrukcijah, saj so ustrezen in dostopen način za doseganje omenjenih vrednot. Učencu predstavljajo orodje za doseganje lastnih ciljev, najpogosteje cilja »imeti«, kar mu posledično omogoča zdravo tekmovalnost in ga obvaruje pred izolacijo. Inštrukcije so dopolnitev formalnega izobraževanja in učencu pomagajo zviševati lastni intelektualni kapital. S prilagajanjem poučevanja osebnostnim lastnostim in potrebam učenca se izboljšujejo tudi njegove ocene $v$ formalnem izobraževanju (Glass v Dessy, St-Amour, \& Vencatachellum, 1998).

Nedvomno je »izobraževanje v senci« dobrodošel in pomemben način za izboljšanje učnega uspeha učencev, dijakov in študentov. V procesu inštruiranja sta tako inštruktor kot inštruiranec ciljno usmerjena. Zato ni nujno, da to vpliva na dejansko pridobljeno znanje in kompetence, saj so fokusirani predvsem v izboljšanje ocen (Vukovič, Perozzi, \& Raspor, 2019).

\subsection{Razvoj in utemeljitev raziskovalnega vprašanja}

Sklicujoč se na avtorje, ki opažajo povečanje časa za instrukcije (Andersen, Humlum, \& Nandrup, 2016; Chingtham, 2015) in prej opisano teoretično ozadje raziskovalnega problema, smo v prispevku iskali vzroke za povečanje uporabnikov inštrukcij, predvsem morebiten vpliv kraja bivanja in izobrazbe staršev na intenzivnost inštrukcij. Osredotočili smo se na naravoslovne predmete kot so fizika, kemija, matematika ter na en tuj jezik. Družbene spremembe se odražajo $\mathrm{v}$ šolstvu in vplivajo na izobraževalne procese, posledično pa tudi na »izobraževanje v senci« - inštrukcije. Naloga je obravnavala dve ključni problematiki: prvič spremembe $\mathrm{v}$ intenzivnost inštrukcij med sredno in osnovnošolsko stopnjo ter med generacijami, ki so bile deležne vpliva družbenih sprememb, in kot drugo na raziskovanje vzrokov fenomena večje intenzivnosti »izobraževanja v senci«.

$\mathrm{V}$ raziskavi smo se med drugim osredotočili na povezavo med izobrazbo in prebivališčem staršev otrok, ki obiskujejo inštrukcije ter njihovo intenzivnostjo. Za namene raziskave smo temu primerno oblikovali naslednje raziskovalno vprašanje: »Ali bivališče uporabnikov in izobrazba njihovih staršev vplivata na intenzivnost inštrukcij? «« in predlagali dve raziskovalni hipotezi:

Napaka! Vira sklicevanja ni bilo mogoče najti. 
H.2: Učenci in dijaki z višješolsko izobraženimi starši se inštrukcij poslužujejo bolj pogosto.

Model predstavljamo v spodnji sliki (glej sliko 1.).



Slika 1. Model raziskave

\section{Metoda}

Pri raziskavi je bilo uporabljenih več metod zbiranja podatkov. Anketirali smo osnovnošolce, dijake gimnazij, srednjih strokovnih in poklicnih šol, ter študente, vpisane v visokošolske študijske programe na Goriškem. Pri tem smo upoštevali tudi časovno komponento sprememb intenzivnosti koriščenja inštrukcij, glede na stopnjo izobraževanja in generacije. Kvantitativni raziskavi smo po pregledu intervjujev udeležencev inštrukcij in njihovih staršev dodali še vsebinsko presojo koristi inštrukcij. Intervjuje smo izvedli še $\mathrm{z}$ učitelji fizike, kemije, matematike in angleškega jezika na osnovnošolskem in srednješolskem nivoju izobraževanja. Na ta način smo uspeli pridobili njihova mnenja glede razlogov za razširjenost in potrebe po uporabi inštrukcij med formalnim izobraževanjem. Pri raziskavi smo med koristnikih inštrukcij uporabili še metodo opazovanja z udeležbo.

Podatke o populaciji šolarjev (devetošolcev), dijakov in študentov na Goriškem smo v glavnem zbirali s Statističnega urada (SURS, 2019), za tiste, ki niso bili dostopni preko spletnega portala, smo Statistični urad posebej zaprosili.

Na območju Goriške se nahajata dve mestni šoli: Osnovna šola Milojke Štrukelj, s podružnično šolo Ledine in Osnovna šola Frana Erjavca; primestna Osnovna šola Solkan s podružničnima šolama Grgar in Trnovo; in pet podeželskih šol: Osnovna šola Branik, Osnovna šola Čepovan, Osnovna šola Brda in Osnovna šola Dornberk s podružnico v Prvačini. Izmed dveh mestnih, ene primestne, peterice podeželskih šol, in tistih podružničnih, smo med tistimi, ki so se na anketo odzvale, izbrali po eno naključno šolo iz vsakega od obravnavanih območij. Kot je razvidno v spodnji tabeli (glej Tabela 1. Populacija devetošolcev v šolskem letu 2016/17 v goriški regiji), je obsegala populacija šolarjev devetega razreda v šolskem letu 2016/17 na vseh osnovnih šolah goriške regije skupno 438 otrok. Od teh smo uspeli anketirati 97 otrok, kar je 22,15\% celotne populacije. Anketirane 
učence smo med tistimi, ki so se odzvali, naključno izbrali. Anketiranje smo tako izvedli v eni primestni šoli in dveh podeželskih.

Tabela 1. Populacija devetošolcev v šolskem letu 2016/17 v goriški regiji

\begin{tabular}{lr}
\hline Občina zavoda & 9. razred \\
\hline Brda & 37 \\
Miren - Kostanjevica & 30 \\
Nova Gorica & 269 \\
Renče - Vogrsko & 34 \\
Šmpeter - Vrtojba & 68 \\
SKUPAJ & 438 \\
Anketiranih & 97 \\
$\%$ anket/populacijo & $22,15 \%$ \\
\hline
\end{tabular}

Povzeto po SURS (2019).

Srednješolska populacija na Goriškem je v šolskem letu 2016/17 obsegala 2.777 dijakov in dijakinj. Ti so se bili vpisani v različne programe: od nižjega poklicnega, srednje-tehničnega in drugih štiriletnih strokovnih in splošnega srednješolskega programa. Vključili smo tudi poklicne in maturitetne tečajnike (glej Tabela 2. Populacija dijakov po izobraževalnih ustanovah šol. leto 2016/17 v goriški regiji).

Tabela 2. Populacija dijakov po izobraževalnih ustanovah šol. leto 2016/17 v goriški regiji

\begin{tabular}{lr}
\hline Dijaki po vrsti zavoda in statistični regiji zavoda, Slovenija, letno 2016/17 & Št. dijakov \\
\hline Gimnazija Nova Gorica & 661 \\
Šolski center Nova Gorica, Biotehniška šola Skupaj & 414 \\
Šolski center Nova Gorica, Elektrotehniška in računalniška šola Skupaj & 464 \\
Šolski center Nova Gorica, Gimnazija in zdravstvena šola Skupaj & 381 \\
Šolski center Nova Gorica, Srednja ekonomska in trgovska šola Skupaj & 362 \\
Šolski center Nova Gorica, Strojna, prometna in lesarska šola Skupaj & 495 \\
SKUPAJ & 2.777 \\
Anketiranih & 66 \\
$\%$ anket/populacijo & 2,38 \\
\hline
\end{tabular}

Povzeto po SURS (2019).

Anketirali smo naključnih 66 srednješolk in srednješolcev, kar predstavlja 2,37 \% celotne populacije. Nizek delež anketirane populacije je posledica nezainteresiranosti izobraževalnih ustanov za anketiranje, saj je bila kljub kontaktiranju vseh srednješolskih izobraževalnih ustanov na Goriškem, odzivnost nizka. V času anketiranja smo imeli na Goriškem tri večje zavode za terciarno izobraževanje: Univerzo v Novi Gorici (UNG), Evropsko pravno fakulteto (EPF) in Fakulteto za uporabne družbene študije (FUDŠ), pa tudi nekatere druge manjše ustanove za pridobivanje terciarne izobrazbe.

Kot je razvidno iz tabele (glej Tabela 3. Populacija terciarnega izobraževanja v šolskem letu 2016/17 v goriški regiji), je bilo v letu 2016/17 v programe terciarnega izobraževanja vpisanih vsega 1.447 študentk in študentov. Med vsemi smo jih anketirali 48, kar je 3,32 \% celotne študentske populacije na Goriškem, kar je nekoliko boljši odziv kot na nižji izobraževalni 
stopnji, a vseeno nizek. K anketiranju smo povabili vse ustanove terciarnega izobraževanja, odzivi so bili naključni.

Podatke o vpisu študentov smo zajemali s stanja na dan 15.10.2017 in nanašajo na tekoče izkazano študijsko leto.

Tabela 3. Populacija terciarnega izobraževanja v šolskem letu 2016/17 v goriški regiji

\begin{tabular}{lr}
\hline Študenti terciarnega izobraževanja po: vrsti izobraževalnega programa, občini: Nova Gorica & Študijsko leto \\
in Šempeter-Vrtojba & $2016 / 17$ \\
\hline Višje strokovno & 140 \\
Visokošolsko strokovno (prejšnje) & - \\
Visokošolsko strokovno (1. bolonjska stopnja) & 352 \\
Visokošolsko univerzitetno (1. bolonjska stopnja) & 536 \\
Visokošolsko univerzitetno (prejšnje) & - \\
Magistrsko (2. bolonjska stopnja) - enovito magistrsko & 70 \\
Magistrsko (2. bolonjska stopnja) - po končani 1. bolonjski stopnji & 317 \\
Specialistično & - \\
Magistrsko (prejšnje) & - \\
Doktorsko (prejšnje) & - \\
Doktorsko (3. bolonjska stopnja) & 32 \\
GORIŠKA REGIJA SKUPAJ & 1.447 \\
Anketiranih & 48 \\
\% anket/populacijo & 3,32 \\
\hline
\end{tabular}
Povzeto po SURS (2019).

Anketiranje je bilo izvedeno v obdobju med 15. februarjem in 15. junijem 2017. Podatke za potrebe naše raziskave smo zbirali s pomočjo anketnega vprašalnika in polstrukturiranega intervjuja, ki je vseboval 16 okvirnih vprašanj za izvajalce izobraževanja. Anketni vprašalnik za učence, dijake in študente pa je vseboval 14 vprašanj. V nadaljevanju navajamo le tista vprašanja, ki so relevantna za ta članek. Vključeval je demografske podatke (vrsta šole, kraj bivanja, spol, starost, stopnja izobrazbe staršev) in vprašanja, ki se nanašajo na predmet raziskave (intenzivnost inštrukcij, potrebe po inštrukcijah, vzroki za inštrukcije, ipd.).

Podatke anketnih vprašalnikov smo obdelali s programskim orodjem SPSS (Specializirani program za statistične analize). Opravili smo univariantne in bivariantne statistične analize. Podatke polstrukturiranih intervjujev s pedagoškimi delavci pa smo obdelali z odprtim kodiranjem vsebine.

\section{Rezultati}

$\mathrm{Z}$ raziskavo smo med drugim želeli ugotoviti, kako pogosto anketiranci koristijo inštrukcije glede na kraj bivanja in izobrazbo staršev. V spodnji tabeli (glej Tabela 4. Uporabniki inštrukcij glede na kraj bivanja) so anketiranci razvrščeni glede na kraj bivanja in koriščenje oziroma nekoriščenje inštrukcij. Skupno je pri anketi sodelovalo 211 anketirancev.

Iz tabele (glej Tabela 4. Uporabniki inštrukcij glede na kraj bivanja) je jasno, da je uporabnikov inštrukcij najmanj enega predmeta kar 63,51 \% vseh anketirancev. Od tega 
$31,34 \%$ anketirancev živi v mestu, $18,66 \%$ v predmestju, $50 \%$ pa jih živi na podeželju. Glede na te podatke, prve hipoteze, da se učenci in dijaki, bivajoči v mestu, inštrukcij poslužujejo bolj pogosto, kakor tisti izven mest, ni mogoče potrditi. Z manj kot $5 \%$ tveganjem ne moremo trditi, da bi bivališče vplivalo na pogostost koriščenja inštrukcij. Slednje dokazujemo s Hi-kvadrat testi $\left(\mathrm{X}^{2}=1,9\right.$ in $\left.\mathrm{p}>0,05\right)$, ki so prikazani v spodnji tabeli (Tabela 5. Hi-kvadrat testi uporabniki inštrukcij glede na kraj bivanja), kjer je signifikanca pri Pearsonovem $\chi^{2}$ testu znašala 0,386 , kar pomeni, da je $p>0,05$, in statistično značilne povezanosti med spremenljivkama ni. Omejitev raziskave seveda je, da je vzorec še vedno majhen.

Tabela 4. Uporabniki inštrukcij glede na kraj bivanja

\begin{tabular}{crrrr}
\hline & \multicolumn{3}{c}{ V katerem okolju živiš? } & \\
\hline instrukcije & mestno & primestno & podeželje & skupaj \\
& 28 & 18 & 31 & 77 \\
nimam inštrukcij & $36,36 \%$ & $23,38 \%$ & $40,26 \%$ & $100,00 \%$ \\
& $40,00 \%$ & $41,86 \%$ & $31,63 \%$ & $36,49 \%$ \\
& $13,27 \%$ & $8,53 \%$ & $14,69 \%$ & $36,49 \%$ \\
imam inštrukcije & 42 & 25 & 67 & 134 \\
& $31,34 \%$ & $18,66 \%$ & $50,00 \%$ & $100,00 \%$ \\
& $60,00 \%$ & $58,14 \%$ & $68,37 \%$ & $63,51 \%$ \\
skupaj & $19,91 \%$ & $11,85 \%$ & $31,75 \%$ & $63,51 \%$ \\
& 70 & $43,18 \%$ & 98 & 211 \\
& $100,00 \%$ & $100,00 \%$ & $100,00 \%$ & $100,00 \%$ \\
& $33,18 \%$ & $20,38 \%$ & $46,45 \%$ & $100,00 \%$ \\
\hline
\end{tabular}

Tabela 5. Hi-kvadrat testi uporabniki inštrukcij glede na kraj bivanja

\begin{tabular}{lccc}
\hline Statistika & Vrednost & prost.st. & Asymp. Sig. (2-tailed) \\
\hline Pearsonov Hi-kvadrat & 1,90 & 2 &, 386 \\
Razmerje verjetij & 1,91 & 2 &, 384 \\
Linear-by-Linear Association & 1,36 & 1 &, 243 \\
N veljavnih enot & 211 & & \\
\hline
\end{tabular}

Tako hipoteze »Napaka! Vira sklicevanja ni bilo mogoče najti.«

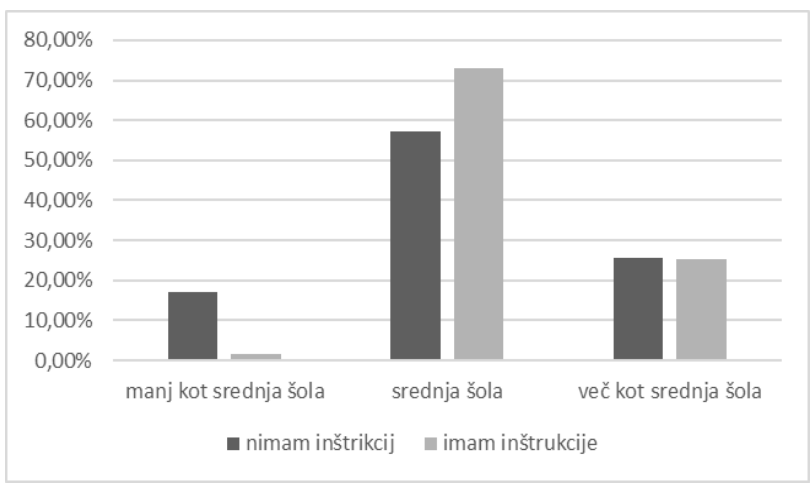

Slika 2. Inštrukcije in dosežena izobrazba staršev 
Anketirance, ki so na vprašanje o izobrazbi svojih staršev odgovorili $\mathrm{z}$ »ne vem«, smo iz analize morali izvzeli (glej Tabela 5. Hi-kvadrat testi uporabniki inštrukcij glede na kraj bivanja, Tabela 6. Dosežena izobrazba staršev izobrazba staršev in Slika 2. Inštrukcije in dosežena izobrazba staršev). Iz rezultatov je razvidno, da inštrukcije koristi le 1,4 \% anketirancev s starši, ki imajo izobrazbo nižjo od srednješolske, 73,13 \% je takšnih, ki imajo starše s srednješolsko izobrazbo, 25,37 \% ima starše z višjo izobrazbo od srednješolske.

Glede na analizo ima največ staršev anketiranih koristnikov inštrukcij srednješolsko izobrazbo (glej Tabela 6. Dosežena izobrazba staršev izobrazba staršev).

Tabela 6. Dosežena izobrazba staršev izobrazba staršev

\begin{tabular}{lrrrr}
\hline \multicolumn{5}{c}{ Kakšna je najvišja dosežena formalna izobrazba vaših staršev? } \\
\hline instrukcije & manj kot srednja šola & srednja šola & več kot srednja šola & \multicolumn{1}{c}{ skupaj } \\
& 6,00 & 20,00 & 9,00 & 35,00 \\
nimam inštrukcij & $17,14 \%$ & $57,14 \%$ & $25,71 \%$ & $100,00 \%$ \\
& $85,71 \%$ & $28,99 \%$ & $34,62 \%$ & $34,31 \%$ \\
& $5,88 \%$ & $19,61 \%$ & $8,82 \%$ & $34,31 \%$ \\
imam inštrukcije & 3,60 & $-3,68$ &, 08 &, 00 \\
& 1,00 & 49,00 & 17,00 & 67,00 \\
& $1,49 \%$ & $73,13 \%$ & $25,37 \%$ & $100,00 \%$ \\
& $14,29 \%$ & $71,01 \%$ & $65,38 \%$ & $65,69 \%$ \\
skupaj &, $98 \%$ & $48,04 \%$ & $16,67 \%$ & $65,69 \%$ \\
& $-3,60$ & 3,68 &,- 08 &, 00 \\
& 7,00 & 69,00 & 26,00 & 102,00 \\
& $6,86 \%$ & $67,65 \%$ & $25,49 \%$ & $100,00 \%$ \\
& $100,00 \%$ & $100,00 \%$ & $100,00 \%$ & $100,00 \%$ \\
& $6,86 \%$ & $67,65 \%$ & $25,49 \%$ & $100,00 \%$ \\
\hline
\end{tabular}

Glede na pridobljene rezultate lahko z manj kot $5 \%$ tveganja potrdimo, da izobrazba staršev vpliva na koriščenje inštrukcij. To dokazujemo s Hi-kvadrat testom, ki znaša 9,8, pri Pearsonovem $\chi 2$ testu je signifikanca manjša od 0,05 , kar sicer pomeni, da je povezanost med spremenljivkama statistično značilna in rezultat velja za celotno populacijo.

Hipoteze vseeno ne moramo potrditi, ker se ob višanju stopnje izobrazbestaršev, koriščenje inštrukcij ne povečuje (glej Tabela 7. Hi-kvadrat testi Dosežena izobrazba staršev izobrazba staršev). Najvišji delež koristnikov inštrukcij med anketiranci opažamo pri tistih, ki imajo srednješolsko izobražene starše. Slednje lahko nakazuje tudi, da učencem in dijakom, ki imajo bolj izobražene starše, ti lažje pomagajo pri šolskih obveznostih. 
Tabela 7. Hi-kvadrat testi Dosežena izobrazba staršev izobrazba staršev

\begin{tabular}{lccc}
\hline & Vrednost & prost.st. & Asymp. Sig. (2-tailed) \\
\hline Pearsonov Hi-kvadrat & 9,08 & 2 &, 011 \\
Razmerje verjetij & 8,83 & 2 &, 012 \\
Linear-by-Linear Association & 1,85 & 1 &, 174 \\
N veljavnih enot & 102 & & \\
\hline
\end{tabular}

Na podlagi rezultatov smo ugotovili, da statistično značilno ne velja in ne moremo potrditi hipoteze »H.2: Napaka! Vira sklicevanja ni bilo mogoče najti.«

Obe svoji domnevi smo preverjali tudi preko intervjujev z udeleženci inštrukcij in njihovimi starši ter učitelji fizike, kemije, matematike in angleškega jezika v osnovnih in srednjih šolah. Vključena je bila tudi metoda opazovanja $\mathrm{z}$ udeležbo samega izvajalca raziskave, ki je dolgoletni inštruktor. Tako tudi sami ne zaznavajo, da bi kdo bolj koristil inštrukcije, zaradi kraja bivanja ali izobrazbe staršev. Kot faktor potrebe po inštrukcijah navajajo samo predznanje inštruiranca, učni uspeh (ali je ta na meji za pozitivno oceno ali pa za oceno, ki jim omogoča boljše pogoje za vpis v nadaljnji študij), njegovo motivacijo za študij (prehodnost, dokazovanje pred vrstniki, višja ocena) in preference staršev, ki bi želeli svojemu otroku pomagati ali ga spodbuditi pri študiju. Prav slednje je včasih pomembno, saj starši zaradi plačljivosti inštrukcij pričakujejo, da se bodo njihovi otroci naučili (npr.za pozitivno oceno). Tega se od rednega obiskovanja šole ne pričakuje vedno. Izjava enega od staršev je bila: »Plačal sem ti inštrukcije in sedaj se moraš naučiti za pozitivno!«.

\section{Razprava}

Glede na zgoraj navedeno lahko na raziskovalno vprašanje "Ali bivališče uporabnikov in izobrazba njihovih staršev vplivata na intenzivnost inštrukcij? « odgovorimo, da bivališče inštruiranca in izobrazba njegovih staršev, na intenzivnost inštrukcij nimata vpliva. Sama raziskava ni dala jasnih odgovorov, čemu je to tako. Potrebna bi bila poglobljena raziskava z večjim vzorcem, ki bi zajel celotno območje Slovenije, da bi dobili bolj relevantno sliko. Na podlagi metode z udeležbo terenska raziskovalka, ki je soavtorica prispevka ugotavlja (saj je namreč tudi sama inštruktorica), da je vzrokov več. Najprej gre za to, da želijo vsi, ne glede na kraj bivanja oz. izobrazbo staršev, otrokom nuditi čim več. Razlik med mestom, in podeželjem, vsaj na Goriškem, kjer je bila izvedena raziskava ni, saj se klasično podeželje spreminja in se precej družin odloča za selitev iz mesta na podeželje. Tako se na podeželje s ciljem da bi živeli v bolj umirjenem okolju v lastni hiši selijo tudi bolj izobraženi in premožni, ki so prej živeli $\mathrm{v}$ večstanovanjskih objektih. To tudi spreminja izobrazbeno strukturo tradicionalnega vaškega okolja.

Za osebe, ki bivajo na podeželju, še bolj pa za tiste, ki so se iz mesta preselili na podeželje, se ugotavlja, da se zavedajo, da so zdravo in mirno okolje, povezanost z naravo, pa tudi manjši vpliv raznih motečih mestnih dejavnikov, pomembni za razvoj njihovih otrok. Posledično izhaja najvišji delež inštruirancev iz podeželja, sledijo jim uporabniki iz primestja. Starši z 
višjimi izobrazbami pa se znajo bolje angažirati pri učnem delu z otroki in jim lahko v tej smeri ponudijo širši spekter pomoči. Prav s tega vidika lahko predpostavimo, da imajo otroci z višje izobraženimi starši manjšo potrebo po učni pomoči in posledično manj inštrukcij, kakor otroci $\mathrm{s}$ srednješolsko izobraženimi starši. Delež inštruirancev $\mathrm{s}$ srednješolsko izobraženimi starši je tako v naši anketi presegel 70 \%, kar kaže, da se starši teh otrok zavedajo pomena izobrazbe, a jim pri šolskem delu, zaradi pomanjkanja znanja ali drugih razlogov, ne zmorejo pomagati, želijo pa, da bi bil otrok v šolanju uspešen. Pri starših, katerih izobrazba je nižja od srednješolske, smo ugotovili, da si ti inštrukcij finančno ne morejo privoščiti v tolikšnem obsegu, kot bi si to želeli. V prihodnje bi zato kazalo raziskati povezavo med dohodki in inštrukcijami. To bi nam dalo odgovore ali si lahko vsi finančno privoščijo inštrukcije.

Tovrstne socialne razlike so se pokazale tudi v času izolacije in študija na daljavo, ko smo bili priča virusu COVID-19 (Cahapay, 2020). Starši, ki nimajo ustreznega znanja, niso bili v stanju, da bi pomagali svojim otrokom pri študiju na daljavo. Po drugi strani pa so starši z boljšo izobrazbo in boljšimi družinskimi dohodki lahko svojim otrokom nudili bodisi njihovo pomoč ali boljšo informacijsko tehnologijo in dostop do spletnih inštrukcij. Tako se taka oblika študija, ki je sicer potekal v izrednih razmerah, lahko pa se ponovi tudi v naslednjem šolskem letu, pokazala na velike razlike. To je bil eden največjih eksperimentov v zadnjem času, na katerega nismo bili pripravljeni (Orehovec, 2020).

\section{Zaključek}

V uvodu smo si zastavili raziskovalno vprašanje: "Ali bivališče uporabnikov in izobrazba njihovih staršev vplivata na intenzivnost inštrukcij? « Na podlagi izvedenega anketiranja dijakov, intervjujev s inštruktorji, učitelji in opazovanjem z udeležbo, smo ugotovili, da kraj bivanja in izobrazba staršev ne vplivata na intenzivnost koriščenja inštrukcij. To lahko vzamemo kot pozitivno ugotovitev, saj nismo zaznali večjega razslojevanja. Splošno pa je precej zaskrbljujoče, da postajajo inštrukcije nekaj pričakovanega. To seveda zmanjšuje individualno odgovornost posameznega pedagoga za kakovost lastnega dela in uspešnost učenca/dijaka/študenta. To nekaterim pedagoškim delavcem omogoča, da učencev v najslabšem primeru tudi ničesar ne naučijo, saj so lahko prepričani, da bodo s pomočjo inštrukcij ti vseeno dosegali tudi mednarodne standarde znanja. Dosežki slovenskih dijakov so se od osamosvojitve dalje bistveno popravili, čeprav se metode poučevanja $\mathrm{v}$ formalnem izobraževalnem sistemu niso bistveno reformirale. Odgovornost za doseganje zastavljenih standardov so z ramen pedagoških delavcev morali prevzeti kar sami učenci in (finančno) njihovi starši, posledično pa je padla na ramena inštruktorjev.

Za razliko od običajnih pedagoških delavcev, so inštruktorji velikokrat pod pritiskom staršev, ki zahtevajo doseganje zastavljenih ciljev in odgovornost inštruktorja, ko ti niso doseženi. Za formalni izobraževalni sistem ni značilno, da bi starši do pedagoških delavcev pristopali s pritožbami, da otroke naučijo premalo ali da metoda ni ustrezna, čeprav je v zadnjih letih opaziti porast ponavljanj preizkusov znanja zaradi prevelikega števila negativnih ocen. Tu 
prihaja tudi do nesoglasji med pedagoškimi delavci in inštruktorji, saj prvi velikokrat niso pripravljeni sodelovati $\mathrm{z}$ inštruktorjem. Pri nekaterih pedagoških delavcih je zaznati prepričanje, da so, ker jih plačuje država, odgovorni samo do države, ne pa tudi do staršev, kot velja za inštruktorje, ker te plačujejo starši. Na vseh nivojih izobraževanja je potrebno zbuditi zavest o odgovornosti do uporabnika. Izobraževanje mora bili namenjeno uporabniku in ne sme biti samo sebi namen. Znanje mora uporabniku podajati na način, da ga je ta zmožen usvojiti in postane zanj koristno. V kolikor stremimo k odličnosti v šolstvu in na področju inštrukcij, morajo te temeljiti na utrjenem znanju in ne zgolj na storitveno naravnanemu učenju za izboljšanje ocen. Povpraševanje po inštrukcijah se namreč povečuje prav v obdobju zaključevanja ocen. O tej temi se premalo govori. V kolikor obstoječi šolski sistem ne zmore organizirati dovolj učne pomoči v okviru organiziranega šolanja, so inštrukcije zagotovo ustrezno orodje za utrjevanje snovi. Potrebno pa bo večje sodelovanje učiteljev, staršev in inštruktorjev. Predvsem s ciljem, da se bo iskalo vzroke, zakaj neka snov predstavlja težavo. Velikokrat se namreč dogaja, da več različnih inštrurancev potrebuje pomoč pri snovi, ki so jo obravnavali pri istem učitelju. To pa bi morda že moral biti znak za alarm, da snov ni bila ustrezno podana. Učenci, ki so bolj navdušeni nad učenjem v šoli, bodo tudi bolj sodelovali in se bolj poglobili v snov, ki jim jo učitelji podajo. Ravno tako bodo pri pouku bolj sodelovali, torej se bodo znanje tudi naučili uporabljati, kar je osnovni namen šolanja in šolstva.

Raziskava daje nekaj koristnih informacij tudi za menedžment $\mathrm{v}$ izobraževanju. Tu so mišljeni predvsem ravnatelji osnovnih in srednjih šol in dekani fakultet. V kolikor bi imeli informacije o številu inštruirancev glede na število učencev, dijakov ali študentov na posamezni šoli, predmetu ali celo učiteljev, bi to lahko bil tudi eden od pokazateljev odličnosti posameznega učitelja, predmeta in šole. Velika razlika je namreč, če koristi inštrukcije 5 učencev od 30-ih, za izboljšanje s prav dobre na odlično oceno, ali pa 15 od 30ih, da bi popravili svojo oceno na pozitivno.

Raziskovalci, ki preučujejo življenjske prehode, izpostavljajo podaljševanje mladostniškega obdobja, s tem podaljševanje izobraževanja in nadgrajevanje izobraževalnih kvalifikacij, kar ima za posledico dolgotrajen stik mladih z izobraževalnimi institucijami (Rapuš \& Stepišnik Perdih, 2007). S tega vidika, bi bilo smiselno in nujno v mednarodnih in lastnih raziskavah nadalje spremljati gibanje intenzivnosti koriščenja inštrukcij, kot tudi nadaljevati $\mathrm{s}$ poglobljenim raziskovanjem vzrokov za naraščajoče potrebe po inštrukcijah in seveda morebitnih rešitvah težav, ki se kažejo med koristniki. Iz naše raziskave je namreč jasno, da so inštruiranci pogosto pod velikimi stresi, kar potrjeno povzroča različne oblike čustvenih stisk, travm in depresij. S takšnimi raziskavami bi bilo mogoče pomagati šolskemu sistemu, da bi dosegel ravan, ki je bila dosežena na Finskem in v drugih severnih državah, mu povrniti kredibilnost, ustrezno zmanjšati potrebo po inštrukcijah, in na ta način preprečiti daljnosežne posledice na zdravje učencev, dijakov in študentov.

Sama raziskava žal ni omogočila, da bi se lahko ta teza preverila na širšem območju, kar je njena pomanjkljivost. Ker je pa raziskava omejena le na določeno število šol, učiteljev in 
učencev, ter zajema le Goriško regijo, bi bilo potrebno raziskavo razširiti na celotno območje Republike Slovenije, da bi lahko analizirali stanje na celotnem območju države. To bi nam dalo prave odgovore na vprašanje, zakaj pa prihaja do takšnega porasta inštrukcij in kako bi učitelji to lahko rešili. Prave vzroke pa bi lahko ugotovili le z globinskimi intervjuji in fokusnimi skupinami, kar priporočamo za nadaljnje raziskovanje. Pred celovito reformo šolstva pa bi morali izvesti poglobljeno vseslovensko raziskavo, kjer bi celovito raziskali prisotnost in vzroke za inštrukcije in kako inštrukcije skupaj z drugimi oblikami učne pomoči še bolj integrirati v sam učni proces.

\section{Reference}

1. Andersen, S. C., Humlum, M. K., \& Nandrup, A. B. (2016). Increasing instruction time in school does increase learning. Proceedings of the National Academy of Sciences, 113(27), 7481-7484. doi 10.1073/pnas.1516686113

2. Bray, M. (2006). Private supplementary tutoring: Comparative perspectives on patterns and implications. Compare: A Journal of Comparative and International Education, 36(4), 515-530. doi 10.1080/03057920601024974

3. Bray, M. (2014). The impact of shadow education on student academic achievement: Why the research is inconclusive and what can be done about it. Asia Pacific Education Review, 15(3), 381-389. doi 10.1007/s12564-014-9326-9

4. Bray, M., Kwo, O., \& Jokić, B. (2016). Researching private supplementary tutoring: Methodological lessons from diverse cultures (32. izdaja). Springer International Publishing.

5. Bray, M., \& Kwok, P. (2003). Demand for private supplementary tutoring: conceptual considerations, and socio-economic patterns in Hong Kong. Economics of Education Review, 22(6), 611-620. doi 10.1016/S0272-7757(03)00032-3

6. Cahapay, M. B. (2020). How Filipino parents home educate their children with autism during COVID-19 period. International Journal of Developmental Disabilities, 1-4. doi $10.1080 / 20473869.2020 .1780554$

7. Chingtham, T. (2015). Necessary Evils of Private Tuition: A Case Study. International Organization of Scientific Research Journal of Research \& Methods and Education, 5(2), 6-11.

8. Čakš, A. (2004, 17. maj). Predrage, a včasih potrebne in koristne. Delo.

9. Dedić, Z. R., Jokić, B., Jurko, L., \& Puzić, S. (2005). In the shadow-Private Tutoring in Secondary Education in Croatia: the scope, nature and effects. Zagreb: Institut za društvena istraživanja.

10. Dessy, S., St-Amour, P., \& Vencatachellum, D. (1998, 1. januar). The economics of private tutoring. Pridobljeno na https://www.researchgate.net/publication/5165598_The_Economics_of_Private_Tutoring

11. Evropska komisija. (1996, 29. november). White Paper on education and training. Pridobljeno na https://op.europa.eu/en/publication-detail/-/publication/d0a8aa7a-5311-4eee-904c98fa541108d8/language-en

12. Gardner III, R., Nobel, M. M., Hessler, T., Yawn, C. D., \& Heron, T. E. (2007). Tutoring system innovations: Past practice to future prototypes. Intervention in School and Clinic, 43(2), 71-81. doi 10.1177/10534512070430020701

13. Grašič, A., Kavkler, M., Magajna, L., Lipec Stopar, M., Bregar Golobič, K., Čačinovič Vogrinčič, G., \& Janželj, L. (2010, 13. april). Težave dijakov pri učenju v poklicnem in strokovnem izobraževanju: opredelitev, prepoznavanje, oblike in mreža pomoči: analiza stanja: raziskovalno poročilo. Ljubljana: Ministrstvo Za Šolstvo in Šport. Pridobljeno na http://www.cpi.si/files/cpi/userfiles/Datoteke/Publikacije/Tezave_dijakov_pri_ucenju_raziskovaln o_porocilo.pdf 
14. Jarić Dauenhauer, N. (2014, 9. december). Gotovo pola hrvatskih učenika ide na instrukcije. Pridobljeno na https://www.tportal.hr/vijesti/clanak/gotovo-pola-hrvatskih-ucenika-ide-nainstrukcije-20141209

15. Joyal, M., Yardley, J. C., \& McDougall, I. (2009). Greek and Roman education: A sourcebook. Routledge.

16. Kassotakis, M., \& Verdis, A. (2013). Shadow education in Greece. V M. Bray. A. E. Mazawi, R. G. Sultana (ur.), Private Tutoring Across the Mediterranean (str. 93-113). Rotterdam: Sense Publishers.

17. Krajnc, A. (1979). Metode izobraževanja odraslih : andragoška didaktika. Ljubljana: Delavska enotnost.

18. Magajna, L., Čačinovič Vogrinčič, G., Kavkler, M., Pečjak, S., \& Bregar Golobič, K. (2008). Učne težave v osnovni šoli: koncept dela: program osnovnošolskega izobraževanja. Ljubljana: Zavod RS za šolstvo.

19. Mauritius Ministry of Education and Science. (1994). Use and Abuse of Private Tuition.

20. Morgan, H. (2014). Review of research: the education system in finland: a success story other countries can emulate. Childhood Education, 90(6), 453-457. doi 10.1080/00094056.2014.983013

21. OECD (2018, 11. september). Education at a glance. Pridobljeno na https://www.oecdilibrary.org/education/education-at-a-glance-2018_eag-2018-en

22. Orehovec, D. (2020, 13. maj). Okrogla miza: Izobraževanje na daljavo - izkušnje za prihodnost? Pridobljeno na https://www.pei.si/okrogla-miza-izobrazevanje-na-daljavo-izkusnje-za-prihodnost/

23. Pavitra, P. B. S.-H. (2002). Šolanje in cilj človeškega življenja. Radovljica: Didakta.

24. Peček Čuk, M., \& Lesar, I. (2010). Učitelji o vedenjskih reakcijah in učnem uspehu učencev s posebnimi potrebami v redni osnovni šoli. V A. Kobolt (ur.), Izstopajoče Vedenje in Pedagoški Odzivi (str. 165-208). Ljubljana: Pedagoška fakulteta.

25. Perozzi, E. (2018). Izobraževanje v "senci” na Goriškem: primer inštrukcij. Nova Gorica: Fakulteta za Uporabne družbene študije.

26. Perozzi, E., \& Raspor, A. (2020). Odnos različnih generacij do inštrukcij. R. Ovin, \& P. AšaninGole (ur.), Trajnostno poslovanje v sodobni družbi (str. 107-123). Maribor: Doba Fakulteta za uporabne poslovne in družbene študije.

27. Rapuš, P. J. ., \& Stepišnik Perdih, T. (2007). Značilnosti prehodov mladih v smeri statusne praznine. V B. Dekleva, J. Rapuš-Pavel, \& D. Zorc-Maver (ur.), Prehodi v svet dela - izbira ali nuja? (str. 104-123). Ljubljana: Pedagoška fakulteta.

28. Reddy, V., Lebani, L., \& Davidson, C. (2003). Schools out or is it? Out of school interventions for mathematics, science and computer studies for secondary school learners. Pretori: Human Science Research Council.

29. Sahlberg, P. (2014). Finnish lessons 2.0: What can the world learn from educational change in Finland? Teachers College Press.

30. Sobhy, H. (2012). The de-facto privatization of secondary education in Egypt: A study of private tutoring in technical and general schools. Compare: A Journal of Comparative and International Education, 42(1), 47-67. doi 10.1080/03057925.2011.629042

31. SURS, Statistični urad Republike Slovenije (2019, 1. januar). Pridobljeno na https://www.stat.si/statweb

32. Škalič, M. (2016, 1. januar). Finski šolski sistem. Častnik. Pridobljeno na https://www.castnik.si/m-skalic-blog-finski-solski-sistem

33. Ventura, A., \& Jang, S. (2010). Private tutoring through the internet: Globalization and offshoring. Asia Pacific Education Review, 11(1), 59-68. doi 10.1007/s12564-009-9065-5

34. Vukovič, G., Perozzi, E., \& Raspor, A. (2019). Izobraževanje v senci, kot podpora formalnemu izobraževalnemu sistemu timsko ali individualno delo? V M. Maletič, I. Podbregar, M.

Radovanovič, \& P. Šprajc (ur.), Ekosistem organizacij v dobi digitalizacije: konferenčni zbornik (str. 1217-1241). Maribor: Univerzitetna založba Slovenije.

35. Zgaga, P., Pluško, A., Krek, J., Zdenko, M., Kovač Šebart, M., \& Marjanovič Umek, L. (2004). Izobraževanje in izobraževalni sistem. Ljubljana: Urad za makroekonomske analize in razvoj. 
Evelina Perozzi Po osnovni izobrazbi inženir elektrotehnike. Po večletnem delu v razvojnih družbah, kjer je bila $\mathrm{v}$ središču inovacij raznih produkcijskih sistemov in avtomatizaciji proizvodnje, je nadaljevala svojo pot $\mathrm{v}$ izobraževanju otrok na področjih naravoslovja, tako $\mathrm{v}$ srednji, kot tudi $\mathrm{v}$ osnovni šoli, kjer je sodelovala $\mathrm{v}$ projektih za vpeljavo računalnika pri izobraževanju $\mathrm{v}$ osnovni šoli. Nato se je odločila, da bo nadaljevala $\mathrm{z}$ izobraževanjem na Univerzi v Mariboru, na Fakulteti za organizacijske vede, kjer je diplomirala iz informatike v organizaciji in managementu. Sledilo je večletno delo na področju igralništva. Kasneje se je pridružila inovativni skupini v HIT d.d. in tako postala pionirka spletnega igralništva. Temu je sledila drugačna pot, saj se je avtorica odločila, da bo odprla samostojno podjetje $\mathrm{z}$ inštrukcijami iz naravoslovnih predmetov. Tako je, da bi bolje opravljala svoje delo, magistrirala iz medkulturnega managementa. Ravno v okviru tega študija je sledila inovativna raziskava inštrukcij na področju Goriške. Pri svojem delu uporablja znanja, pridobljena na zelo različnih področjih, ki jih je nabrala med več kot 35 leti delovnih izkušenj. Ravno ta raznolikost ji omogoča sodelovanje pri različnih projektih.

$$
* * *
$$

Andrej Raspor Po osnovni izobrazbi strojni tehnik. Po univerzitetnem študiju organizacije dela na Fakulteti za organizacijske vede v Kranju v okviru Univerze v Mariboru, je nadaljeval podiplomski študij na Fakulteti za družbene vede Univerze v Ljubljani in doktoriral leta 2010. Pri svojem delu združuje poslovno in akademsko delo, saj predava, vodi lastno podjetje in svetuje. Ima več kot 35 let delovnih izkušenj, med temi več kot 17 let na različnih vodilnih mestih, od vodje splošnih poslov, direktorja razvoja kadrov, direktorja za strateške projekte in vodje komisije za nadzor stroškov. Raziskovalna dela: Delovna razmerja in procesi s poudarkom na optimizaciji delovnih procesov, tako $\mathrm{z}$ vidika stroškov, kot tudi organizacije delovnega časa; Turizem $\mathrm{s}$ poudarkom na kitajskem izhodnem turizmu, turizmu za ljudi s posebnimi potrebami in trajnostnemu turizmu; Odprte inovacije; Igralništvo. Vodil je več bilateralnih projektov ARRS in sodeluje v INTEREG projektih.

\section{Abstract: \\ The Influence of Place of Residence and Education of Parents on the Intensity of Instruction}

Research question (RQ): Among other questions in this research we have tried to answer, in relation to an increase of the use of tutoring, was whether the intensity of the use of tutoring is influenced by the place of residence and education of parents, so we formulated the following research question: "Does the place of residence and education of parents' affect the use of tutoring?"

Purpose: The basic goal of the research was to determine how extensive the use of tutoring is in the Goriška region and how/if the place of residence and education of parents is relevant. We focused on science subjects such as math, physics, chemistry, and one foreign language.

Method: We surveyed primary school students, high school students, secondary schools, and students enrolled in higher education study programs in the Goriška region. By interviewing both students and parents, a quantitative research was enriched by the detailed content review of the importance of tutoring. We also conducted interviews with teachers of physics, chemistry, mathematics, and English in both primary and secondary education, and gained an insight into the increased use and need of tutoring in the context of formal education. We also used the method of observation by observing the students that use tutors and resort to tutoring. The research was conducted during the 2016/2017 school year.

Results: Based on the data gained by conducting an extensive research, the following key conclusion was formed: Place of residence and education of parents do not affect the intensity of tutoring.

Organization: According to the findings, the volume of tutors is increasing, and students are too focused on improving grades rather than better consolidating learning, school principals and deans could make certain changes in the delivery of learning content to students. When organizing the tutoring, it is important that it directly relates to consolidation of learning, rather than being directed only towards the improvement of grades, which are required for passing and applying for collage. 
Society: The contribution is important from the point of view of students, teachers and also the Ministry of Education in relation to the reform of the school system. Moreover, a broader study could offer solutions to limit the emerging gap between students and teachers, as research has shown that the use of tutoring has increased significantly. Here we should follow the example of those countries where the study is designed in such a way, that there is no need for additional tutoring.

Originality: This is the first such extensive research in the Goriška region and in Slovenia in general. All school levels were included. Starting with elementary schools, high schools and higher education programs. Above all, this study expresses originality, as it seeks to answer how the place of residence and education of parents influence the tutoring process.

Limitations/further research: The limitation of the research is that we conducted the research in the Goriška region only and that the selected sample was small, therefore, the findings cannot be applicable to everyone. It would make sense to conduct similar research and expand it to the entire Slovenian population. Another limitation is the fact that it was carried out before COVID-19, during which teaching, and tutoring had to adapt to the new situation.

Keywords: tutoring, education, individualism, conformism, motivation, generations, parental education, location of parents' residence.

Copyright (c) Evelina PEROZZI, Andrej RASPOR

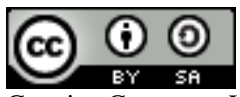

Creative Commons License

This work is licensed under a Creative Commons Attribution-ShareAlike 4.0 International License. 